\title{
Dinamika Populasi Gulma Akibat Aplikasi Herbisida Metil Metsulfuron pada Padi Sawah Sistem Tanam Pindah (Tapin) dan Tanam Benih Langsung (Tabela)
}

\author{
Sri Utami“, Denny Kurniadie, dan Dedi Widayat \\ Departemen Agronomi, Fakultas Pertanian Universitas Padjadjaran \\ Jl. Raya Bandung-Sumedang KM 21 Jatinangor Jawa Barat 45363 \\ *Alamat korespondensi: sri16017@mail.unpad.ac.id
}

\author{
ABSTRACT
Weed population dynamics due to the application of metsulfuron-methyl herbicide in transplanted rice and direct-seeded rice

Changes in dominance and composition of weed species become a problem that often arise to weed control, especially weed control using herbicides. Weeds can become more dangerous, difficult to control and resistant if not handled properly. Changes in species and composition are also influenced by crop cultivation system. The purpose of this study was to determine the shift or change weeds dominance and composition due to the application of the herbicide metsulfuron-methyl in transplanted and direct-seeded rice. The design experiment used in this research was split plot design with four replications. The main plot was cultivation system with two levels: transplanted rice $\left(\mathrm{T}_{1}\right)$ and direct-seeded rice $\left(\mathrm{T}_{2}\right)$, whereas the sub plot was weed control with three levels: weed control using herbicides metsulfuron-methyl $\left(\mathrm{H}_{1}\right)$, manual weeding $\left(\mathrm{H}_{2}\right)$ and no weeding or control $\left(\mathrm{H}_{3}\right)$. The results showed that the dominance of weeds changed from broadleaf to sedges, except in control treatment of direct-seeded rice $\left(\mathrm{T}_{2} \mathrm{H}_{3}\right)$. Treatment of metsulfuron-methyl in direct-seeded rice $\left(\mathrm{T}_{2} \mathrm{H}_{1}\right)$ has the most different level of weed community similarity as compared to initial Anveg and control treatment in transplanted rice $\left(\mathrm{T}_{1} \mathrm{H}_{3}\right)$ and direct-seeded rice $\left(\mathrm{T}_{2} \mathrm{H}_{3}\right)$. Weed diversity decreased, especially in the treatment of herbicide metsulfuron-methyl with direct-seeded rice $\left(\mathrm{T}_{2} \mathrm{H}_{1}\right)$ which had the lowest level of weed diversity and highest dominating value.

Keywords: Weed shifting, Metsulfuron-methyl, Transplanted, Direct-seeded.

\begin{abstract}
ABSTRAK
Perubahan jenis, komposisi dan dominasi gulma merupakan masalah yang sering timbul akibat adanya pengendalian gulma, terutama pengendalian gulma menggunakan herbisida. Gulma dapat menjadi lebih berbahaya, sulit dikendalikan dan menjadi resisten jika tidak diatasi dengan baik. Perubahan jenis dan komposisi juga dipengaruhi oleh sistem budidaya tanaman. Penelitian ini bertujuan untuk mengetahui pergeseran atau perubahan gulma akibat aplikasi herbisida metil metsulfuron pada penanaman padi sistem Tapin dan sistem Tabela. Penelitian ini menggunakan rancangan split plot yang diulang sebanyak empat kali. Faktor utama adalah sistem tanam dengan dua taraf, yaitu sistem Tabela $\left(\mathrm{T}_{2}\right)$ dan Tapin $\left(\mathrm{T}_{1}\right)$. Anak petak adalah penyiangan gulma dengan tiga taraf, yaitu penyiangan menggunakan herbisida metil metsulfuron $\left(\mathrm{H}_{1}\right)$, penyiangan manual $\left(\mathrm{H}_{2}\right)$ dan tanpa penyiangan atau kontrol ( $\left.\mathrm{H}_{3}\right)$. Hasil penelitian menunjukan bahwa kecuali pada perlakuan kontrol pada sistem Tabela $\left(\mathrm{T}_{2} \mathrm{H}_{3}\right)$, dominasi gulma berubah dari gulma golongan daun lebar menjadi gulma golongan teki. Perlakuan herbisida metil metsulfuron sistem Tabela $\left(\mathrm{T}_{2} \mathrm{H}_{1}\right)$ memiliki tingkat kesamaan komunitas gulma yang paling berbeda terhadap Anveg awal dan perlakuan kontrol pada sistem Tapin $\left(\mathrm{T}_{1} \mathrm{H}_{3}\right)$ maupun Tabela $\left(\mathrm{T}_{2} \mathrm{H}_{3}\right)$. Keanekaragaman gulma menurun, terutama pada perlakuan herbisida metil metsulfuron sistem Tabela $\left(\mathrm{T}_{2} \mathrm{H}_{1}\right)$ yang memiliki tingkat keanekaragaman gulma paling rendah dan nilai dominsi paling tinggi.
\end{abstract}

Kata kunci: Pergeseran gulma, Metil-metsulfuron, Tapin, Tabela 


\section{PENDAHULUAN}

Keberadaan gulma merupakan salah satu masalah yang dapat mengakibatkan kehilangan hasil pada padi sawah. Besarnya kehilangan hasil salah satunya ditentukan oleh cara budidaya tanaman itu sendiri (Singh et al., 2016). Budidaya tanaman padi sawah dapat dilakukan dengan cara Tanam Pindah (Tapin) dan Tanam Benih Langsung (Tabela). Sistem Tapin merupakan cara tanam yang memiliki resiko rendah dan cara budidaya yang paling sederhana. Menurut Aruan \& Mariati (2010) kelemahan dari sistem Tapin adalah pengolahan tanah yang boros air serta penggunaan tenaga kerja dalam jumlah yang relatif banyak. Sistem Tabela umumnya digunakan di daerah Indonesia yang kekurangan air dan tenaga kerja. Menurut Pitojo (2006) penggunaan sistem Tabela mampu menghemat tenaga kerja dan penggunaan air serta mampu meningkatkan hasil tanaman persatuan luas. Salah satu permasalahan dari sistem Tabela adalah kehadiran gulma yang melimpah, sehingga mengakibatkan kehilangan hasil yang cukup besar.

Ramzan (2003) mengungkapkan bahwa kehilangan hasil akibat gulma pada pertanaman padi sistem Tapin adalah $48 \%$, sementara pada sistem Tabela sebesar 78\%. Rao et al. (2007) dalam Hossain et al. (2016) mengungkapkan bahwa tingkat kerugian akibat gulma pada tanaman padi sistem Tabela 50\% lebih tinggi dibandingkan sistem Tapin. Kerugian tersebut terjadi akibat tumbuhnya gulma yang bersamaan dengan benih tanaman padi, sementara gulma memiliki kemampuan tumbuh yang lebih cepat dibandingkan tanaman (Raj \& Syriac, 20017). Pertumbuhan gulma yang cepat mengakibatkan tingkat kerapatan gulma yang tinggi serta morfologi gulma yang mirip tanaman padi menjadikan pengendalian gulma pada sistem Tabela semakin sulit dikendalikan (Pane, 2003).

Pengendalian gulma pada pertanaman padi dapat dilakukan dengan berbagai cara, salah satunya dengan menggunakan herbisida. Salah satu herbisida yang dapat digunakan pada pertanaman padi sistem Tapin dan Tabela adalah herbisida metil metsulfuron. Herbisida metil metsulfuron merupakan herbisida golongan sulfonilurea yang bekerja dengan cara menghambat kerja enzim acetoacetate pembentuk asam amino tumbuhan (Raj \& Syriac, 2017). Herbisida metil metsulfuron diserap tumbuhan melalui daun dan akar yang kemudian ditranslokasikan ke bagian meristematik tumbuhan (Vencill, 2002). Menurut Marble et al. (2016) herbisida metil metsulfuron mampu mengendalikan gulma golongan daun lebar dan rumput. Tumbuhan yang terkena herbisida metil metsulfuron umumnya memperlihatkan gejala klorosis dan nekrosis pada 2 minggu setelah aplikasi dan pada akhirnya mati (Marble et al., 2016; Raj \& Syriac, 2017)

Penggunaan sistem budidaya dan herbisida yang berbeda mengakibatkan terjadinya pergeseran jenis dan komposisi gulma ke arah yang berbeda. Perubahan sistem tanam Tapin menjadi Tabela mengakibatkan gulma bergeser menjadi jenis rumput atau teki yang lebih berbahaya dan sulit untuk dikendalikan (Kumar \& Ladha, 2011; Singh et al., 2016). Hal ini dapat terjadi akibat jumlah air yang digunakan pada awal pertanaman sistem Tabela yang lebih sedikit, sehingga gulma rumput dan teki tumbuh lebih baik dibandingkan gulma daun lebar (Singh et al., 2016). Pergeseran koposisi dan dominasi gulma sendiri akan menjadi semakin berbahaya dan lebih sulit dikendalikan ketika sistem tanam atau herbisida yang sama digunakan berulang secara terusmenerus. Ramiraz et al. (2017) mengungkapkan bahwa penggunaan herbisida yang sama secara terusmenerus dalam waktu yang cukup lama dapat mengakibatkan gulma sulit untuk dikendalikan dan dalam kondisi terburuk mengakibatkan gulma menjadi resisten. Pengamatan terhadap perubahan komposisi gulma dalam jangka pendek masih jarang dilakukan. Menurut Wibawa et al. (2009) pengamatan gulma dalam jangka pendek perlu dilakukan untuk mengetahui cara pengendalian gulma pada musim berikutnya, selain itu dapat menjadi panduan atas perubahan gulma yang terjadi pada musim mendatang. Penelitian ini dilakukan untuk mengetahui perubahan komposisi gulma dalam jangka pendek akibat penggunaan sistem tanam maupun penggunaan herbisida metil metsulfuron.

\section{BAHAN DAN METODE}

Penelitian dilakukan di kebun percobaan Fakultas Pertanian Universitas Padjadjaran, Ciparay Kabupaten Bandung Jawa Barat. Penelitian dilakukan selama 4 bulan, yaitu bulan November 2018 sampai Maret 2019. Rancangan yang digunakan berupa split plot yang disusun secara RAK (Rancangan Acak Kelompok). Faktor pertama adalah sistem tanam padi, yang terdiri atas Sistem Tapin $\left(\mathrm{T}_{1}\right)$ dan Tabela $\left(\mathrm{T}_{2}\right)$. Faktor kedua berupa jenis pengendalian gulma, yaitu pengendalian dengan menggunakan herbisida metil metsulfuron $\left(\mathrm{H}_{1}\right)$, pengendalian manual $\left(\mathrm{H}_{2}\right)$ yang dilakukan dua kali (15 dan 30 HST) dan tanpa pengendalian $\left(\mathrm{H}_{3}\right)$. Percobaan tersebut terdiri atas 3 
perlakuan yang diulang sebanyak 4 kali sehingga terdapat 12 satuan petak percobaan. Herbisida diaplikasikan menggunakan alat semprot punggung semi-otomatis volume $400 \mathrm{lt} / \mathrm{ha}$ dan menggunakan nozel T-jet bertekanan $1 \mathrm{~kg} / \mathrm{cm}^{2}(15-20 \mathrm{psi})$.

Pengamatan yang dilakukan berupa analisis vegetasi (Anveg) terhadap gulma. Anveg dilakukan dengan mengambil gulma contoh menggunakan kuadrat berukuran $0,5 \times 0,5 \mathrm{~m}$, kemudian gulma dipisahkan dan dihitung jumlahnya berdasarkan spesies. Selanjutnya dilakukan analisis data untuk mengetahui dominasi (SDR) gulma dan Koefisien Komunitas (C) gulma berdasarkan Tjitrosoedirdjo dkk. (1984), Indeks Keanekaragaman (H') berdasarkan Shannon-Wiener dan Indeks Dominasi gulma (D) Simpson (Magurran, 2013; Khadka et al., 2016). Secara lebh rinci, pengamatan yang dilakukan adalah sebagai berikut:

\section{Analisis vegetasi}

Nilai analisis vegetasi diperoleh dari data pengamatan analisis vegetasi awal (Anveg awal) dan data Anveg 5 MSA (Minggu Setelah Aplikasi). Menurut Tjitrosoedirjo, $d k k$. (1984) analisis vegetasi gulma meliputi:

\section{Kerapatan}

$\begin{aligned} \text { Kerapatan mutlak } & =\frac{\text { Jumlah individu jenis }}{\text { Jumlah plot }} \\ \text { Kerapatan Relatif } & =\frac{\text { KM suatu jenis }}{\text { KM semua jenis }} \text { X 100\% }\end{aligned}$

2. Frekuensi

$$
\begin{aligned}
& \text { Frekuensi mutlak }=\frac{\text { Jumlah plot spesies itu beradas }}{\text { Jumlah plot }} \\
& \text { Frekuensi Relatif }=\frac{\text { FM suatu jenis }}{\text { FM semua jenis }} \text { X 100\% }
\end{aligned}
$$

3. Dominasi

Dominasi Mutlak

$$
\frac{\text { Jumlah individu jenis tersebut }}{\text { Jumlah plot di mana jenis tersebut berada }}
$$

Dominasi Relatif $=\frac{\mathrm{DM} \text { suatu jenis }}{\mathrm{Dm} \text { semua jenis }} \times 100 \%$

4. Nilai Penting Suatu Jenis

Nilai Penting $=\mathrm{KN}+\mathrm{DN}+\mathrm{FN}$

5. SDR (Summed Dominance Ratio)

$$
\mathrm{SDR}=\frac{\text { Nilai Penting }}{3}
$$

\section{Koefisien komunitas (C)}

Nilai koefisien komunitas diperoleh dari data pengamatan yang dilakukan pada saat Anveg awal dan Anveg 5 MSA dengan nilai tolak ukur tercantum dalam Tabel 1. Menurut Tjitrosoedirdjo, dkk. (1984) nilai koefisien komunitas (C) dapat dihitung dengan rumus sebagai berikut:

$$
C=2 \frac{W}{A+B} \times 100 \%
$$

Keterangan:

W : Jumlah dari dua kuantitas terendah untuk jenis dari masing-masing komunitas

A : Jumlah dari seluruh kuantitas pada komunitas pertama

B : Jumlah dari seluruh kuantitas pada komunitas kedua

Tabel 1. Nilai tolak ukur koefisien komunitas (Bonham, 1989).

\begin{tabular}{cl}
\hline Nilai tolak ukur & \multicolumn{1}{c}{ Keterangan } \\
\hline $91 \%-100 \%$ & Terdapat kesamaan komunitas yang sangat tinggi (sangat sama) \\
\hline $71-90 \%$ & Terdapat kesamaan komunitas yang sama (sama) \\
\hline $56-70 \%$ & Tingkat kesamaan komunitas yang mirip (mirip) \\
\hline $45-55 \%$ & Tingkat kesamaan renadah atau berbeda (berbeda) \\
\hline$<45 \%$ & Tingkat kesamaan sangat berbeda (sangat berbeda) \\
\hline
\end{tabular}

\section{Indeks keanekaragaman spesies (H')}

Nilai indeks keanekaragaman spesies gulma dihitung berdasarkan data yang diperoleh dari pengamatan Anveg awal dan Anveg 5 MSA. Keanekaragaman jenis ditentukan dengan menggunakan rumus Indeks Keanekaragaman Shannon-Wiener (Magurran, 2013; Khadka et al., 2016).

$$
\mathrm{H}^{\prime}=-\sum_{n=i}^{n}\left(\frac{n i}{N}\right)\left(\ln \frac{n i}{N}\right)
$$

Keterangan:

H' = Indeks diversitas
$\mathrm{Ni}=$ Jumlah nilai penting suatu jenis

$\mathrm{N}=$ Jumlah seluruh total nilai penting

Ln = Logaritme natural

Tabel 2. Nilai tolak ukur indeks keanekaragaman (Barbour et al., 1987; Djufri, 2003)

\begin{tabular}{cl}
\hline Nilai tolak ukur & \multicolumn{1}{c}{ Keterangan } \\
\hline $\mathrm{H}^{\prime} \leq 1$ & Keanekaragaman sangat rendah \\
\hline $1<\mathrm{H}^{\prime} \leq 2$ & Keanekaragaman rendah \\
\hline $2<\mathrm{H}^{\prime} \leq 3$ & Keanekaragaman sedang \\
\hline $3<\mathrm{H}^{\prime} \leq 4$ & Keanekaragaman tinggi \\
\hline $\mathrm{H}^{\prime}>4$ & Keanekaragaman sangat tinggi \\
\hline
\end{tabular}




\section{Indeks dominasi gulma (D)}

Nilai Indeks dominan gulma diperoleh dari data Anveg awal dan Anveg 5 MSA. Nilai indeks dominasi gulma dianalisis dengan menggunakan rumus Indeks Simpson (Magurran, 2013; Khadka et al., 2016) dengan nilai tolak ukur tersaji pada Tabel 3.

$$
\mathrm{D}=\sum_{\mathrm{i}=1}^{\mathrm{S}} \mathrm{Pi} 2
$$

Keterangan:

$\mathrm{C}=$ Indeks Simpson

$\mathrm{S}=$ Jumlah Species

$\mathrm{Pi}=\mathrm{ni} / \mathrm{N}$ yakni proporsi gulma jenis $\mathrm{i}$ dan seluruh guLma (ni = jumlah gulma jenis $\mathrm{i}, \mathrm{N}=$ Jumlah seluruh gulma dalam total $\mathrm{n}$ ).

Tabel 3. Nilai tolak ukur indeks dominansi (Magurran, 2013; Khadka et al., 2016).

\begin{tabular}{clc}
\hline Nilai tolak ukur & \multicolumn{1}{c}{ Keterangan } \\
\hline $\mathrm{D}<1$ & $\begin{array}{l}\text { Tidak terdapat spesies yang } \\
\text { mendominasi }\end{array}$ & \\
\hline $\mathrm{D}=1$ & $\begin{array}{l}\text { Terdapat spesies } \\
\text { mendominasi }\end{array}$ & yang \\
\hline
\end{tabular}

\section{HASIL DAN PEMBAHASAN}

\section{Komposisi dan dominasi gulma}

Hasil analisis vegetasi awal ditemukan 7 spesies gulma, yaitu gulma Ludwigia repens, Monochoria vaginalis, Limnocharis flava, Marsilea crenata, Fimbristylis miliacea, Scirpus juncoides, dan Cynodon dactilon. Sebelum perlakuan herbisida, lahan percobaan didominasi oleh gulma daun lebar dengan SDR 56,12 \% disusul oleh gulma teki dengan SDR 35,35\% (Tabel 4). Dari Tabel 4 dapat dilihat bahwa petak tanpa penyiangan $\left(\mathrm{H}_{3}\right)$ pada sistem Tabela ( $\left.\mathrm{T}_{2}\right)$ didominasi oleh gulma daun lebar dengan SDR 70,46\% sejalan dengan pengamatan Anveg awal, sedangkan pada petak tanpa penyiangan $\left(\mathrm{H}_{3}\right)$ dengan sistem Tapin $\left(\mathrm{T}_{1}\right)$ terjadi perubahan dominansi dari golongan daun lebar menjadi gulma teki dengan SDR $36,03 \%$.

Hasil pengamatan menunjukan bahwa akibat perlakuan herbisida metil metsulfuron $\left(\mathrm{H}_{1}\right)$ maupun penyiangan manual $\left(\mathrm{H}_{2}\right)$ pada sistem Tapin $\left(\mathrm{T}_{1}\right)$ dan Tabela $\left(\mathrm{T}_{2}\right)$ memperlihatkan pola perubahan dominansi yang sama dari gulma golongan daun lebar menjadi gulma golongan teki. Berdasarkan keadaan tersebut dapat diartikan bahwa pada sistem Tapin $\left(\mathrm{T}_{1}\right)$ dan Tabela $\left(\mathrm{T}_{2}\right)$, baik dengan herbisida (metil metsulfuron) maupun manual mengakibatkan pergeseran dominasi gulma dari golongan daun lebar menjadi teki (Tabel 1). Perubahan jumlah dominasi tersebut terjadi akibat adanya pengendalian gulma seperti penggunaan herbisida maupun penyiangan manual (Christoffoleti et al., 2008). Gulma Fimbristylis miliacea merupakan gulma dominan yang ditemukan sebelum maupun setelah perlakuan. Kondisi tersebut memperlihatkan bahwa gulma $F$. miliacea merupakan gulma yang sulit dikendalikan dan cukup tahan herbisida metil metsulfuron. Schaedler et al. (2015) mengungkapkan bahwa gulma F. miliacea merupakan salah satu gulma yang cukup tahan terhadap herbisida sulfonilurea dan telah dilaporkan menjadi gulma resisten herbisida sulfonilurea di beberapa negara.

Tabel 4. Pengaruh herbisida metil metsulfuron terhadap komposisi dan dominasi gulma pada pertanaman padi sawah sistem Tapin dan Tabela.

\begin{tabular}{|c|c|c|c|c|c|c|c|c|}
\hline \multirow{3}{*}{ Nama gulma } & \multirow{3}{*}{ Gol } & \multirow{3}{*}{$\begin{array}{c}\text { Anveg } \\
\text { awal }\end{array}$} & \multicolumn{6}{|c|}{ Anveg akhir (5 MSA) } \\
\hline & & & \multicolumn{3}{|c|}{ Tapin } & \multicolumn{3}{|c|}{ Tabela } \\
\hline & & & $\mathrm{T}_{1} \mathrm{H}_{1}$ & $\mathrm{~T}_{1} \mathrm{H}_{2}$ & $\mathrm{~T}_{1} \mathrm{H}_{3}$ & $\mathrm{~T}_{2} \mathrm{H} 1$ & $\mathrm{~T}_{2} \mathrm{H}_{2}$ & $\mathrm{~T}_{2} \mathrm{H}_{3}$ \\
\hline L. repens & \multirow{4}{*}{ DL } & \multirow{4}{*}{56,12} & \multirow{4}{*}{27,96} & \multirow{4}{*}{37,50} & \multirow{4}{*}{28,72} & \multirow{4}{*}{6,02} & \multirow{4}{*}{38,73} & \multirow{4}{*}{70,46} \\
\hline M. vaginalis & & & & & & & & \\
\hline L. flava & & & & & & & & \\
\hline M. crenata & & & & & & & & \\
\hline F. miliacea & \multirow{2}{*}{$\mathrm{T}$} & \multirow[t]{2}{*}{35,35} & \multirow[t]{2}{*}{44,92} & \multirow[t]{2}{*}{44,44} & \multirow[t]{2}{*}{36,03} & \multirow[t]{2}{*}{67,78} & \multirow[t]{2}{*}{61,27} & \multirow{2}{*}{29,5} \\
\hline S. juncoides & & & & & & & & \\
\hline C. dactilon & \multirow{2}{*}{$\mathrm{R}$} & \multirow{2}{*}{8,53} & \multirow[t]{2}{*}{27,12} & \multirow[t]{2}{*}{18,06} & \multirow[t]{2}{*}{35,25} & \multirow[t]{2}{*}{26,20} & \multirow[t]{2}{*}{0,00} & \multirow[t]{2}{*}{0,00} \\
\hline E. crus-galli & & & & & & & & \\
\hline Jumlah SDR & & 100 & 100 & 100 & 100 & 100 & 100 & 100 \\
\hline
\end{tabular}

Keterangan: $\mathrm{T}_{1}$, Tapin; $\mathrm{T}_{2}$, Tabela; $\mathrm{H}_{1}$, herbisida metil metsulfuron; $\mathrm{H}_{2}$, Penyiangan manual; $\mathrm{H}_{3}$, Kontrol; DL, Daun lebar; $\mathrm{R}$, rumput; $\mathrm{T}$, teki. 


\section{Indeks koefisien komunitas gulma (C)}

Indeks koefisien komunitas gulma (C) merupakan suatu cara yang dilakukan untuk mengetahui tingkat kesamaan antara komunitas satu dengan yang lainnya (Fachrul, 2007). Besarnya nilai C ditentukan berdasarkan penilaian Bonham (1989) yang menyebutkan bahwa dua komunitas atau vegetasi bisa dikatakan sama jika memiliki nilai $\mathrm{C}$ diatas $70 \%$. Hasil analisis data memperlihatkan bahwa tidak ada perlakuan yang memiliki kesamaan dengan hasil analisis vegetasi awal, kecuali pada perlakuan tanpa penyiangan $\left(\mathrm{H}_{3}\right)$ pada sistem Tapin $\left(\mathrm{T}_{1}\right)$ maupun Tabela $\left(\mathrm{T}_{2}\right)$ (Tabel 5). Hal ini menunjukan bahwa pengendalian gulma mengakibatkan perubahan jumlah dan komposisi gulma pada sistem Tapin maupun Tabela. Menurut Rao (2000) perrubahan komposisi gulma selalu terjadi pada setiap jenis pengendalian gulma, terutama pengendalian menggunakan herbisida. Hasil penelitian Calha et al. (1995) memperlihatkan bahwa penggunaan herbisida metil metsulfuron secara terus-menerus selama 3-4 tahun mendorong munculnya gulma Alisma plantago-aquatica. Sementara itu menurut Mercado (1979) pengendalian gulma secara manual dapat merubah komposisi gulma menjadi gulma tahunan (Cyperus rotundus dan Echinochloa crusgalli), diamana hal ini terjadi akibat akar yang tertinggal saat pengendalian dlakukan.

Pengamatan yang dilakukan antar perlakuan pada sistem Tapin $\left(\mathrm{T}_{1}\right)$ memperlihatkan bahwa tingkat kesamaan antar komunitas perlakuan berada dalam kategori yang mirip hingga sama (56-90\%). Pengamatan antar perlakuan pada sistem Tabela $\left(\mathrm{T}_{2}\right)$ memperlihatkan bahwa tingkat kesamaan komunitas antar perlakuan berada dalam kategori berbeda hingga sangat berbeda (0-55\%), yang artinya tidak terdapat kesamaan komunitas antar perlakuan. Hasil perbandingan antara perlakuan sistem Tapin (T1) dengan sistem Tabela (T2) memperlihatkan tingkat kesamaan antar perlakuan yang mirip hingga sama. Kondisi tersebut menandakan bahwa perlakuan pada sistem Tabela $\left(\mathrm{T}_{2}\right)$ memiliki perubahan gulma yang lebih tinggi, terutama pada perlakuan herbisida metil metsulfuron. Wibawa et al. (2009) mengungkapkan bahwa suatu komunitas gulma dianggap telah berubah jika memiliki nilai koefisien komunitas rendah atau berada di bawah $56 \%$.

Tabel 5. Pengaruh herbisida metil metsulfuron terhadap indeks koefisien komunitas gulma pada pertanaman padi sawah sistem Tapin dan Tabela

\begin{tabular}{|c|c|c|c|c|c|c|c|}
\hline & & \multirow{2}{*}{ Anveg awal } & \multicolumn{3}{|c|}{ Tapin (T1) } & \multicolumn{2}{|c|}{ Tabela (T2) } \\
\hline & & & $\mathrm{H}_{1}$ & $\mathrm{H}_{2}$ & $\mathrm{H}_{3}$ & $\mathrm{H}_{1}$ & $\mathrm{H}_{2}$ \\
\hline \multirow{3}{*}{ 蒬 } & $\mathrm{H}_{1}$ & 60 & & & & & \\
\hline & $\mathrm{H}_{2}$ & 57 & 73 & & & & \\
\hline & $\mathrm{H}_{3}$ & 76 & 71 & 63 & & & \\
\hline \multirow{3}{*}{ 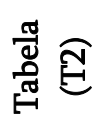 } & $\mathrm{H}_{1}$ & 36 & 65 & 55 & 43 & & \\
\hline & $\mathrm{H}_{2}$ & 63 & 53 & 75 & 51 & 43 & \\
\hline & $\mathrm{H}_{3}$ & 76 & 65 & 57 & 77 & 40 & 54 \\
\hline
\end{tabular}

Keterangan: $\mathrm{T}_{1}$, Tapin; $\mathrm{T}_{2}$, Tabela; $\mathrm{H}_{1}$, herbisida metil metsulfuron; $\mathrm{H}_{2}$, Penyiangan manual; $\mathrm{H}_{3}$, Kontrol.

\section{Indeks keanekaragaman spesies $\left(\mathrm{H}^{\prime}\right)$}

Nilai indeks keanekaragaman spesies digunakan untuk menyatakan suatu ukuran yang menggambarkan variasi spesies tumbuhan dari suatu komunitas. Hasil Anveg awal memperlihatkan nilai indeks keanekaragaman ( $\left.\mathrm{H}^{\prime}\right)$ gulma berada dalam kategori rendah $(1,85)$ (Tabel 6). Setelah perlakuan diketahui bahwa terjadi penurunan nilai $\mathrm{H}$, namun sebagian besar perlakuan $\left(\mathrm{T}_{1} \mathrm{H}_{1}, \mathrm{~T}_{1} \mathrm{H}_{2}, \mathrm{~T}_{1} \mathrm{H}_{3}, \mathrm{~T}_{2} \mathrm{H}_{2}\right.$ dan $\mathrm{T}_{2} \mathrm{H}_{3}$ ) tetap berada dalam kategori rendah dengan nilai $\mathrm{H}$ berkisar antara 1,31 - 1,79. Menurut Setiadi (2004) kondisi tersebut menandakan bahwa keanekaragamaan gulma pada lahan penelitian cukup homogen. Pengamatan lebih rinci memperlihatkan bahwa nilai indeks keanekaragamaan paling rendah terdapat pada perlakuan herbisida metil metsulfuron sistem Tabela $\left(\mathrm{T}_{2} \mathrm{H}_{1}\right)$ yang berada dalam kategori sangat rendah $(0,98)$. Hal ini memperlihatkan bahwa herbisida metil metsulfuron pada sistem tanam Tabela lebih efektif dibandikan pada sistem Tapin. Efektifitas herbisida terhadap gulma dipengaruhi oleh beberapa hal, diantaranya dipengaruhi oleh cara budidaya dan kondisi lingkungan tumbuh tanaman (Hoerlein, 1994 dalam Mohamad dkk., 2010; Matzenbacher et al., 2014). Cara budidaya pada sistem Tapin dan Tabela mengakibatkan kondisi iklim mikro pada kedua pertanaman berbeda, sehingga efektifitas herbisida pada kedua sistem 
tanam tersebut berbeda. Perbedaan efektifitas herbisida sendiri pada akhirnya mampu merubah komposisi dan keseragaman gulma pada suatu lahan (Wrucke \& Arnold, 1985 Swanton et al., 1993).

Tabel 6. Pengaruh herbisida metil metsulfuron terhadap indeks keragaman gulma pada pertanaman padi sawah sistem Tapin dan Tabela

\begin{tabular}{|c|c|c|}
\hline \multicolumn{2}{|c|}{ Pengamatan } & $\begin{array}{c}\text { Indeks Keragaman Gulma } \\
\left(\mathrm{H}^{\prime}\right)\end{array}$ \\
\hline \multicolumn{2}{|c|}{ Anveg awal } & 1,85 \\
\hline \multirow{6}{*}{$\sum_{n}^{\mathbb{S}}$} & $\mathrm{T}_{1} \mathrm{H}_{1}$ & 1,60 \\
\hline & $\mathrm{T}_{1} \mathrm{H}_{2}$ & 1,31 \\
\hline & $\mathrm{T}_{1} \mathrm{H}_{3}$ & 1,76 \\
\hline & $\mathrm{T}_{2} \mathrm{H}_{1}$ & 0,98 \\
\hline & $\mathrm{T}_{2} \mathrm{H}_{2}$ & 1,35 \\
\hline & $\mathrm{T}_{2} \mathrm{H}_{3}$ & 1,79 \\
\hline
\end{tabular}

Keterangan: $\mathrm{T}_{1}$, Tapin; $\mathrm{T}_{2}$, Tabela; $\mathrm{H}_{1}$, herbisida metil metsulfuron; $\mathrm{H}_{2}$, Penyiangan manual; $\mathrm{H}_{3}$, Kontrol.

Berdasarkan hasil pengamatan diketahui bahwa tanpa adanya perlakuan herbisida $\left(\mathrm{H}_{2}\right.$ dan $\left.\mathrm{H}_{3}\right)$, tingkat keragaman gulma lebih tinggi pada sistem Tabela ( $\left.\mathrm{T}_{2}\right)$ dibandingkan sistm Tapin $\left(\mathrm{T}_{1}\right)$. Sementara itu pada pemberian herbisida $\left(\mathrm{H}_{1}\right)$ memperlihatkan tingkat keragaman gulma pada sistem Tabela $\left(\mathrm{T}_{2}\right)$ lebih rendah dibandingkan Tapin $\left(\mathrm{T}_{1}\right)$. Hal tersebut kemungkinan terjadi akibat herbisida yang diaplikasikan pada 20 HST mengendalikan gulma lebih baik pada sistem Tabela $\left(\mathrm{T}_{2}\right)$ dibandingkan sistem Tapin $\left(\mathrm{T}_{1}\right)$. Tumbuhnya tanaman bersamaan dengan tumbuhnya gulma mengakibatkan jumlah dan keragaman gulma pada sistem Tabela $\left(\mathrm{T}_{2}\right)$ yang tinggi, sehingga pada saat aplikasi herbisida gulma lebih banyak terkendalikan. Sementara pada sistem Tapin $\left(\mathrm{T}_{1}\right)$ tanaman tumbuh lebih dahulu, sehingga gulma terlambat tumbuh dan mengakibatkan pengendalian gulma kurang berhasil.

\section{Indeks dominasi gulma (D)}

Nilai Indeks dominansi (D) merupakan nilai yang digunakan untuk mengetahui kekayaan spesies serta keseimbangan jumlah individu setiap spesies dalam suatu ekosistem. Hasil Anveg awal memperlihatkan nilai $\mathrm{D}$ sebesar 0,17 , kemudian mengalami kenaikan setelah perlakuan diberikan (Tabel 7). Semakin tinggi nilai indeks dominasi menandakan bahwa terdapat spesies tertentu yang menguasai lahan (Mawazin \& Subiakto, 2013). Secara lebih rinci hasil pengamatan memperlihatkan bahwa perlakuan herbisida metil metsulfuron pada sistem
Tabela $\left(\mathrm{T}_{2} \mathrm{H}_{1}\right)$ memberikan nilai $\mathrm{D}$ tertinggi, sementara pada perlakuan Tapin $\left(\mathrm{T}_{1} \mathrm{H}_{1}\right)$ memperlihatkan nilai $\mathrm{D}$ yang lebih rendah dari perlakuan penyiangan manual pada Tapin $\left(\mathrm{T}_{1} \mathrm{H}_{2}\right)$. Pengamatan terhadap perlakuan tanpa pentiangan (kontrol) pada sistem Tapin $\left(\mathrm{T}_{1} \mathrm{H}_{3}\right)$ dan Tabela $\left(\mathrm{T}_{2} \mathrm{H}_{3}\right)$ memperlihatkan nilai D yang paling rendah. Kondisi tersebut menandakan bahwa perlakuan herbisida metil metsulfuron dengan sisitem Tabela $\left(\mathrm{T}_{2} \mathrm{H}_{1}\right)$ memiliki jumlah spesies gulma yang paling sedikit, sementara pada perlakuan tanpa penyiangan sistem Tabela $\left(\mathrm{T}_{2} \mathrm{H}_{3}\right)$ memiliki jumlah spesies gulma terbanyak. Kondisi tersebut sesuai dengan pernyataan Moorthy \& Dubey (1979) dalam Pane (2003) dimana gulma pada sistem Tabela lebih banyak dibandingkan pada perlakuan sistem Tapin. Sementara itu pengaruh herbisida terhadap gulma dapat berbeda tergantung jenis tanaman, cara budidaya dan kondisi lingkungannya (Hoerlein, 1994 dalam Mohamad dkk., 2010; Matzenbacher et al., 2014).

Tabel 7. Pengaruh herbisida metil metsulfuron terhadap indeks dominasi gulma pada pertanaman padi sawah sistem Tapin dan Tabela

\begin{tabular}{|c|c|c|}
\hline \multicolumn{2}{|c|}{ Pengamatan } & Indeks Dominasi Gulma (D) \\
\hline \multicolumn{2}{|c|}{ Anveg awal } & 0,17 \\
\hline \multirow{6}{*}{ 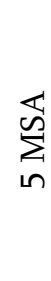 } & $\mathrm{T}_{1} \mathrm{H}_{1}$ & 0,24 \\
\hline & $\mathrm{T}_{1} \mathrm{H}_{2}$ & 0,29 \\
\hline & $\mathrm{T}_{1} \mathrm{H}_{3}$ & 0,20 \\
\hline & $\mathrm{T}_{2} \mathrm{H}_{1}$ & 0,48 \\
\hline & $\mathrm{T}_{2} \mathrm{H}_{2}$ & 0,27 \\
\hline & $\mathrm{T}_{2} \mathrm{H}_{3}$ & 0,19 \\
\hline
\end{tabular}

Keterangan: $\mathrm{T}_{1}$, Tapin; $\mathrm{T}_{2}$, Tabela; $\mathrm{H}_{1}$, herbisida metil metsulfuron; $\mathrm{H}_{2}$, Penyiangan manual; $\mathrm{H}_{3}$, Kontrol

\section{SIMPULAN}

1. Selain pada perlakuan tanpa penyiangan pada sistem Tabela $\left(\mathrm{T}_{2} \mathrm{~h}_{3}\right)$, dominasi gulma di lahan uji mengalami perubahan dari gulma golongan daun lebar menjadi gulma golongan teki.

2. Perlakuan herbisida metil metsulfuron sistem Tabela $\left(\mathrm{T}_{2} \mathrm{H}_{1}\right)$ menyebabkan perubahan komunitas gulma yang paling tinggi dan mengakibatkan tingkat kesamaan koumunitas gulma yang terendah terhadap anveg awal dan perlakuan tanpa penyiangan (kontrol) pada sistem Tapin $\left(\mathrm{T}_{1} \mathrm{H}_{3}\right)$ maupun Tabela $\left(\mathrm{T}_{2} \mathrm{H}_{3}\right)$ 
3. Nilai keanekaragaman gulma mengalami penurunan dan nilai indeks dominasi mengalami kenaikan pada semua perlakuan. Keanekaragaman gulma terendah dan dominasi gulma paling tinggi terdapat pada perlakuan herbisida metil metsulfuron sistem Tabela $\left(\mathrm{T}_{2} \mathrm{H}_{1}\right)$.

\section{DAFTAR PUSTAKA}

Aruan, YL, dan R Mariati.2010. Perbandingan pendapatan usahatani padi (oryza sativa 1.) sawah sistem tanam pindah dan tanam benih langsung di Desa Sidomulyo Kecamatan Anggana Kabupaten Kutai Kartanegara. Jurnal Ekonomi Pertanian dan Pembangunan. 7:3036.

Barbour, GM, JK Burk, and WD Pitts. 1987. Terrestrial Plant Ecology. The Benyamin/Cummings Publishing Company. New York:

Bonham, CD. 1989. Measurement for Terrestrial Vegetation. JohnWiley \& Son. New york.

Calha IM, C Machado, and F Rocha. 1995. A survey of herbicide resistant weeds in Portuguese fields. In Proceedings International Symposium on Weed and Crop Resistance to Herbicides. 223-226.

Christoffoleti, PJ, AJ Galli, SJ Carvalho, MS Moreira, M Nicolai, LL Foloni, BA Martins, and DN Ribeiro. 2008. Glyphosate sustainability in South American cropping systems. Pest Management Science: formerly Pesticide Science. 64:422-427.

Djufri. 2013. Pengaruh tegakan akasia (Acacia nilotica) terhadap komposisi dan keanekaragaman tumbuhan bawah di savana Balanan Taman Nasional Baluran Jawa Timur. Jurnal Ilmiah Pendidikan Biologi. 3:38-50.

Fachrul, MF. 2007. Metode Sampling Bioteknologi. Bumi Aksara. Jakarta.

Hossain, MM, M Begum, M-M Rahman and M-M Akanda. 2016. Weed management on directseeded rice system-a review. Progressive Agriculture. 27:1-8.

Khadka, CB, AL Hammet, A Singh, YP Timilsina, and MK Balla. 2016. Ecological parameters and diversity indices of marsh orchid (Dactylorhiza hatagirea D. Don) and its associates in Lete Village of Mustang District, Nepal. eJournal of Applied Forest Ecology. 4:29-39.

Kumar, V, and JK Ladha. 2011. Direct seeding of rice: recent developments and future research needs. In Advances in Agronomy. 111:297413.

Magurran, AE. 2013. Measuring Biological Diversity. John Wiley \& Sons. New York.

Marble, C, S Jason, KB Timothy, A Black, and E Gilman. 2016. Effects of metsulfuron-methylcontaining herbicides on ornamentals. University of Florida.

Matzenbacher, FO, RA Vidal, A Merotto Jr, and MM Trezzi. 2014. Environmental and physiological factors that affect the efficacy of herbicides that inhibit the enzyme protoporphyrinogen oxidase: a literature review. Planta Daninha. 32:457-463.

Mawazin, dan A Subiakto. 2013. Keanekaragaman dan komposisi jenis permudaan alam hutan rawa gambut bekas tebangan di riau. Indonesian Forest Rehabilitation Journal. 1:59-73.

Mercado, BL. 1979. Introduction to Weed Science.Southeast Asian Regional Center for Graduated Study and Research in Agriculture. Philippines. 292 hal

Mohamad, RB, W Wibaya, MG Mohayidin, AB Puth, AS Juraimi, Y Awang, and M Lassim. 2010. Management of mixed weeds in young oilpalm plantation with selected broad-spectrum herbicides. Pertanika Journal of Tropical Agricultural Science. 33 (2): 193-203.

Pane, H. 2003. Kendala dan peluang pengembangan teknologi padi tanam benih langsung. Jurnal Litbang Pertanian. 22:172-178.

Pitojo, S. 2006. Budidaya Padi Sawah Tabela. Penebar Swadaya. Jakarta. 55 hal.

Raj, SK, and EK Syriac. 2017. Weed management in direct seeded rice: A review. Agricultural Reviews, 38:41-50.

Ramzan, M. 2003. Evaluation of various planting methods in rice-wheat cropping system, Punjab, Pakistan. Rice Crop Report, 2004(2003).4-5.

Schaedler, CE, NR Burgos, JA Noldin, EA Alcober, RA Salas, and D Agostinetto. 2015. Competitive ability of ALS-inhibitor herbicide-resistant Fimbristylis miliacea. Weed Research of An International Journal Weed Biology, Ecology and Vegetation Management. 55: 482-492.

Setiadi, D. 2004. Keanekaragaman spesies tingkat pohon di Taman Wisata Alam Ruteng, Nusa Tenggara Timur. Laboratorium Ekologi Jurusan Biologi FMIPA Institut Pertanian Bogor. 6: 118-122. 
Singh, VP, SP Singh, VC Dhyani, A Banga, A Kumar, $\mathrm{K}$ Satyawali, and N Bisht. 2016. Weed management in direct-seeded rice. Indian Journal of Weed Science. 48:233-246.

Swanton, CJ, DR Clement, and DA Derksen, 1993. Weed succession under conservation tillage: A hierarchical framework for research and management. Weed Tech. 7: 286-297.

Tjitrosoedirdjo, S, IH Utomo, dan J Wiroatmodjo. 1984. Pengelolaan Gulma di Perkebunan. Kerjasama Biotrop Bogor - PT. Gramedia. Jakarta .
Vencill, WK. 2002. Herbicide Handbook (Edisi Kedua). Weed Science Society of America. United State of America.

Wibawa, W, R Mohamad, AS Juraimi, D Omar, MG Mohayidin, and M Begum. 2009. Weed control efficacy and short term weed dynamic impact of three non-selective herbicides in immature oil palm plantation. International Journal of Agriculture and Biology.11:145150.

Wrucke, MA, and WE Arnold, 1985. Weed species distribution as influenced by tillage and herbicides. Weed Science. 33: 853-856. 